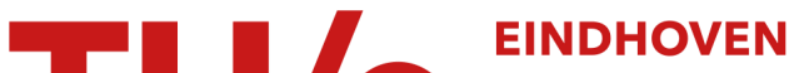

\section{Antibiotic-loaded collagen sponges in clinical treatment of chronic osteomyelitis}

\section{Citation for published version (APA):}

van Vugt, T. A. G., Walraven, J. M. B., Geurts, J. A. P., \& Arts, J. J. C. (2018). Antibiotic-loaded collagen sponges in clinical treatment of chronic osteomyelitis: a systematic review. Journal of Bone and Joint Surgery. American Volume, 100(24), 2153-2161. https://doi.org/10.2106/JBJS.17.01140

DOI:

10.2106/JBJS.17.01140

Document status and date:

Published: 19/12/2018

\section{Document Version:}

Publisher's PDF, also known as Version of Record (includes final page, issue and volume numbers)

\section{Please check the document version of this publication:}

- A submitted manuscript is the version of the article upon submission and before peer-review. There can be important differences between the submitted version and the official published version of record. People interested in the research are advised to contact the author for the final version of the publication, or visit the $\mathrm{DOI}$ to the publisher's website.

- The final author version and the galley proof are versions of the publication after peer review.

- The final published version features the final layout of the paper including the volume, issue and page numbers.

Link to publication

\section{General rights}

Copyright and moral rights for the publications made accessible in the public portal are retained by the authors and/or other copyright owners and it is a condition of accessing publications that users recognise and abide by the legal requirements associated with these rights.

- Users may download and print one copy of any publication from the public portal for the purpose of private study or research.

- You may not further distribute the material or use it for any profit-making activity or commercial gain

- You may freely distribute the URL identifying the publication in the public portal.

If the publication is distributed under the terms of Article 25fa of the Dutch Copyright Act, indicated by the "Taverne" license above, please follow below link for the End User Agreement:

www.tue.nl/taverne

Take down policy

If you believe that this document breaches copyright please contact us at:

openaccess@tue.nl

providing details and we will investigate your claim. 


\title{
Antibiotic-Loaded Collagen Sponges in Clinical Treatment of Chronic Osteomyelitis
}

\author{
A Systematic Review
}

T.A.G. van Vugt, MD, J.M.B. Walraven, MD, J.A.P. Geurts, MD, PhD, and J.J.C. Arts, MSc, PhD

Investigation performed at the Department of Orthopaedic Surgery, Maastricht University Medical Centre (MUMC+), Maastricht, the Netherlands

\begin{abstract}
Background: Chronic osteomyelitis is caused by bacterial infection of the bone and is a major problem in orthopaedic surgery. Treatment of chronic osteomyelitis requires surgical debridement accompanied by local and systemic administration of antibiotics. A widely established biodegradable local antibiotic carrier is antibiotic-loaded collagen sponges (fleeces). These sponges are commonly used in the treatment of chronic osteomyelitis, but a systematic review of their clinical efficacy and assessment of the quality of evidence have not been conducted, to our knowledge.
\end{abstract}

Methods: This systematic review, performed according to the PRISMA statement, examined the clinical efficacy of and quality of evidence regarding different antibiotic-loaded collagen sponges in the clinical treatment of chronic osteomyelitis. Clinical efficacy was defined as eradication of infection with bone and wound-healing. In addition, the in vivo pharmacokinetics of the various collagen sponges were evaluated. Quality was based on the Level of Evidence, methodological quality, and risks of bias.

Results: A total of 813 articles were screened, and 10 were included. Gentamicin-sulfate sponges and gentamicinsulfate/gentamicin-crobefate sponges were studied. A total of 413 patients were treated, with a success rate of $91 \%$. Reported complications were fistulas, prolonged wound drainage, and wound-healing problems. In vivo pharmacokinetic profiles showed an average local antibiotic concentration that was above the minimum inhibitory concentration for only 5 days. The general quality of the included studies was low to moderate, and there was a moderate to high risk of bias.

Conclusions: The evidence quality and Level of Evidence of the included studies were low, and the risk of bias in these studies was high. This makes the evidence regarding these sponges inconclusive, and no clinical decision-making can be based on these studies. Utilization of antibiotic-loaded collagen sponges in the treatment of chronic osteomyelitis should only be carried out with caution; studies with high-level evidence are needed.

Level of Evidence: Therapeutic Level IV. See Instructions for Authors for a complete description of levels of evidence.

$\mathrm{C}$ hronic osteomyelitis is a major problem in orthopaedic surgery ${ }^{1}$. Most infections occur after surgery involving trauma or an orthopaedic implant, but they can also result from hematogenous spread of bacteria. Incidence rates are rising because of the aging population, leading to an increase in (implant-related) surgery. These incidence rates vary from $0.5 \%$ to $2 \%$ in primary hip and knee arthroplasty ${ }^{2,3}$ up to $50 \%$ in surgery for an open fracture ${ }^{4}$.

Treatment of chronic osteomyelitis requires surgical debridement accompanied by local and/or systemic administration of antibiotics ${ }^{5,6}$. It is commonly performed using antibiotic-loaded polymethylmethacrylate (PMMA) beads. A major drawback of PMMA beads is the need for a second surgery to remove them and perform a bone reconstruction ${ }^{7}$. In addition, they could become a local substrate for bacterial colonization and biofilm formation ${ }^{8,9}$. Treatment of chronic osteomyelitis in a 1-stage procedure is preferable, as it lowers the patient burden, shortens hospitalization, and likely lowers health-care costs.

In order to perform 1-stage surgery, a biodegradable antibacterial biomaterial is necessary, and factors such as the degradation properties of the biomaterial, its antibiotic release

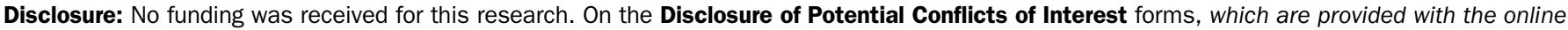

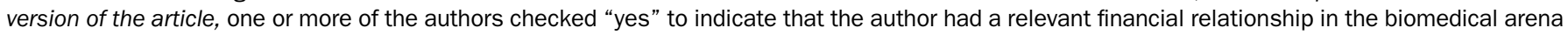

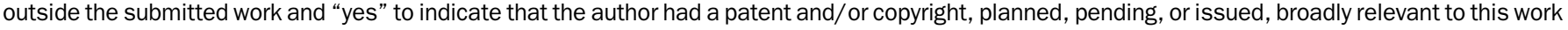
(http://links.Iww.com/JBJS/E939). 
The Journal of Bone \& Joint Surgery $\cdot$ JbJs.org Volume 100-A · Number 24 · December 19, 2018
Antibiotic-Loaded Collagen Sponges in Clinical Treatment of Chronic OSTEOMYelitis (bulk, sustained, or combined), and the tissue penetration of the antibiotic are important in achieving proper local concentrations of the antibiotic ${ }^{10}$. These concentrations must exceed the minimum inhibitory concentration (MIC) for the causative pathogens in order to eradicate the infection ${ }^{11}$. There are numerous biomaterials that are potentially suitable for 1stage treatment of chronic osteomyelitis. These biomaterials are often based on natural or synthetic polymers, or on ceramic materials $s^{7,12}$. A widely used biodegradable natural polymer is collagen. This collagen may be of bovine or equine origin, is generally harvested from skin tissue, consists of collagen type I, and is processed into antibiotic-loaded sponges (fleeces) ${ }^{13,14}$. Possible benefits of collagen sponges are biodegradation, high rates of antibiotic release, manageability of use, and low $\operatorname{cost}^{15,16}$. Degradation of collagen sponges should take place within 2 to 8 weeks, depending on local vascularization ${ }^{17}$. Host macrophages facilitate degradation of the collagen sponge by proteolytic activation ${ }^{18}$. After implantation, antibiotic release is based mainly on diffusion, although sustained release occurs due to degradation of the collagen matrix by macrophages as well ${ }^{14}$.

Over the years, manufacturers of collagen sponges have developed a variety of sponges that are commonly applied in osteomyelitis treatment. However, to our knowledge, the clinical efficacy of these sponges in the treatment of chronic osteomyelitis, and the accompanying quality of the evidence, have never been evaluated, and a proper literature overview of their applicability is lacking. The purpose of this systematic review was to determine the clinical efficacy of antibiotic-loaded collagen sponges in the treatment of patients with chronic osteomyelitis as well as assess the methodological quality and Level of Evidence of the studies.

\section{Materials and Methods}

\section{Eligibility Criteria and Search}

This systematic review is presented in accordance with the 1 PRISMA (Preferred Reporting Items for Meta-Analyses and Systematic Reviews) Statement ${ }^{19,20}$.

Several eligibility criteria were applied in the present study. Only case series, observational studies, and randomized controlled trials (RCTs) regarding the clinical application of antibiotic-loaded collagen sponges in the treatment of chronic osteomyelitis were eligible for inclusion. Articles written in a language other than English or German were excluded. Studies involving patients with osteomyelitis due to any causative mechanism except diabetic ulcer treatment were eligible for inclusion. Patient selection was not further restricted on the

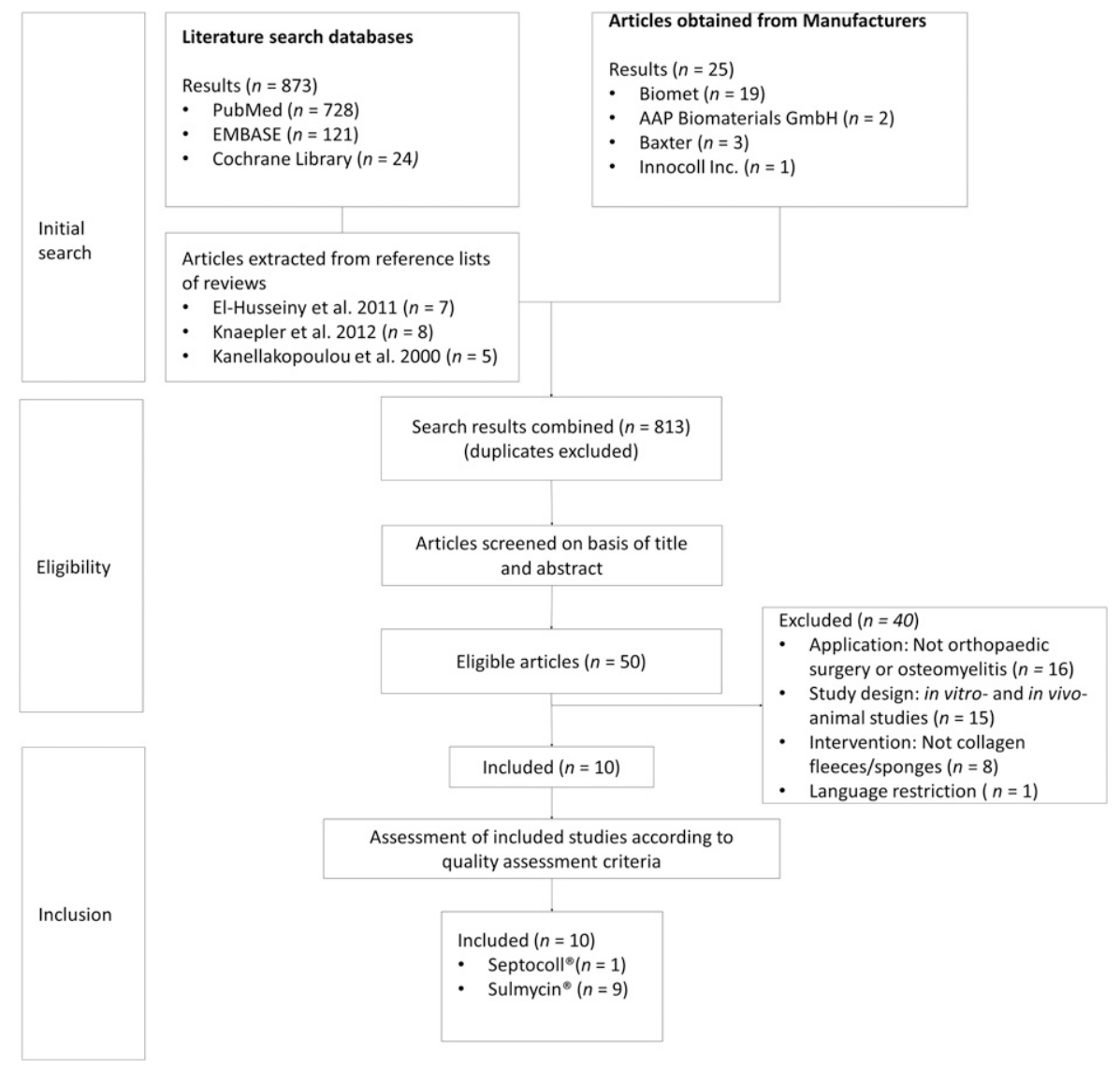

Fig. 1

Flowchart outlining the selection process of eligible manuscripts from different sources. A substantial number of studies were excluded from this systematic review because of the rigid eligibility criteria that were applied. 
The Journal of Bone \& Joint Surgery - JBjs. org Volume 100-A · Number 24 · December 19, 2018
Antibiotic-Loaded Collagen Sponges in Clinical Treatment of Chronic OSTEOMYelitis

\section{TABLE I Commercially Available Antibiotic-Loaded Collagen Sponges and Their Properties}

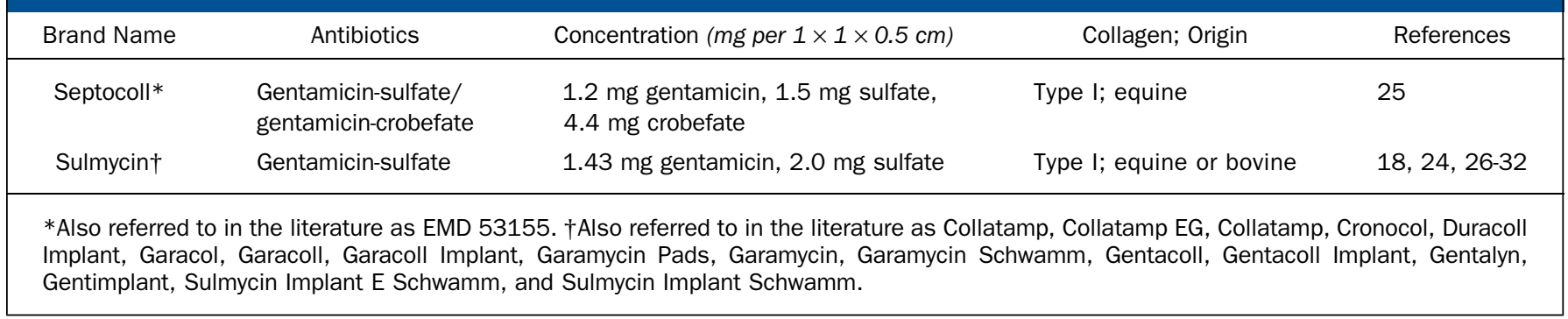

basis of sex, age, or other patient characteristics. The primary outcome of interest was eradication of infection, but studies that reported on secondary outcomes of biodegradability, influence on bone regeneration, and complication rates (woundhealing problems, prolonged wound drainage, etc.) were also eligible for inclusion.

Online electronic databases were used to identify eligible studies. The exact search terms and the search strategies for these databases are shown in the Appendix. In addition, the reference lists of included articles were scanned. Finally, studies were identified by consultation with the manufacturers of collagen sponges. The last search was performed on October 15, 2017.

\section{Data Collection and Analysis}

All identified studies were screened on the basis of the title and abstract by the main author and 1 other author (T.A.G.v.V. and J.M.B.W.). One author extracted the data from the selected studies into a file. Extracted data were verified by 2 other authors working independently (J.M.B.W. and J.J.C.A.). The Level of Evidence was determined according to the methods of the Oxford Centre for Evidence-Based Medicine ${ }^{21,22}$. Bias was assessed on the basis of the Cochrane Collaboration's tool for assessing risk of bias $^{23}$, which was customized so that it was suitable for assessing bias in all study designs rather than only RCTs. Bias was assessed using standardized criteria (see Appendix). The Level of Evidence and bias were independently assessed by 3 authors (T.A.G.v.V., J.M.B.W., and J.J.C.A.) and subsequently discussed to reach a consensus.

\section{Results \\ Included Studies}

A total of 813 articles were identified by various methods, $A$ and 10 studies $^{18,24-32}$ were included after screening on the basis of the title and abstract (Fig. 1). The remaining articles were excluded for a variety of reasons such as use of collagen sponges in applications other than treatment of osteomyelitis/ osteitis, study designs of the wrong type, and studies that were preclinical in nature or were performed in animals.

The 10 selected studies varied in study design, article type, and outcome measurements, and involved 2 different antibiotic-loaded sponges (Table I). Gentamicin-sulfate/ gentamicin-crobefate sponge was investigated in $1 \mathrm{RCT}^{25}$, whereas gentamicin-sulfate sponge was investigated in the remaining 9 studies ${ }^{18,24,26-32}$, which included $1 \mathrm{RCT}^{31}, 6$ case series ${ }^{18,24,26,28-30}, 1$ cohort study ${ }^{32}$, and 1 retrospective outcome study $^{27}$ (Table II).

Study characteristics and outcomes are listed in Tables III and IV. Two important outcome measurements were reported

TABLE II Study Design, Methods, and Risk of Bias of the Included Studies

\begin{tabular}{|c|c|c|c|c|}
\hline Product & Study & Study Design & Level of Evidence* & Grade of Recommendation* \\
\hline \multirow[t]{8}{*}{ Sulmycin } & Ascherl et al. $1990^{24}$ & Case series report & I & C \\
\hline & Dieckmann et al. $2008^{27}$ & Retrospective outcome study & IIIb & \\
\hline & Feil et al. $1990^{28}$ & Case series report & IV & \\
\hline & von Hasselbach $1989^{26}$ & Case series report & IV & \\
\hline & Kwasny et al. $1994^{30}$ & Case series report & IV & \\
\hline & Letsch et al. $1993^{31}$ & Randomized controlled trial & $\mathrm{Ilb}$ & \\
\hline & Leung et al. $2015^{32}$ & Cohort study & $\mathrm{Ilb}$ & \\
\hline & Wernet et al. $1992^{18}$ & Case series report & IV & \\
\hline
\end{tabular}


The Journal of Bone \& Joint Surgery Jbjs.org

Volume 100-A · Number 24 - December 19, 2018

Antibiotic-Loaded Collagen Sponges in Clinical Treatment

of Chronic OSTEOMYelitis

TABLE III Characteristics of the Included Studies*

\begin{tabular}{|c|c|c|c|c|}
\hline Study & Indication & Treatment Algorithm & $\begin{array}{l}\text { Patients } \\
\text { (I/C) }\end{array}$ & $\begin{array}{c}\text { Sex } \\
(M / F)\end{array}$ \\
\hline Buehler et al. $2002^{25}$ & com & Debridement, intramedullary implantation & $62 / 61$ & $96 / 27$ \\
\hline Dieckmann et al. $2008^{27}$ & COM, AOM & Debridement, intramedullary implantation & $36 / N A$ & NR \\
\hline Feil et al. $1990^{28}$ & COM, AOM, PJ & Debridement, intramedullary/intra-articular implantation & 64/NA & $38 / 26$ \\
\hline Kwasny et al. $1994^{30}$ & COM, osteitis & Debridement, intramedullary implantation & 49/NA & NR \\
\hline Letsch et al. $1993^{31}$ & $\mathrm{cOM}$ & Debridement, intramedullary implantation & $10 / 10$ & $13 / 7$ \\
\hline Leung et al. $2015^{32}$ & com & Debridement, intramedullary implantation & 50/NA & $35 / 15$ \\
\hline Wernet et al. $1992^{18}$ & $\mathrm{com}$ & Debridement, intramedullary implantation & $47 / N A$ & NR \\
\hline
\end{tabular}

in most or all of the studies. Success of treatment was a primary outcome in all studies and was defined as absence of infection at the end of follow-up. The pharmacokinetics of the antibiotic release were a secondary outcome in 7 studies and were measured by analyzing gentamicin concentrations in wound exudate, blood, and urine. Sponge degradation was assessed in

TABLE IV Outcomes of Included Studies*

\begin{tabular}{|c|c|c|c|c|}
\hline Study & Eradication Rates & Pharmacokinetics $\dagger$ & $\begin{array}{c}\text { Sponge } \\
\text { Degradation }\end{array}$ & 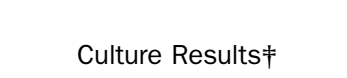 \\
\hline Buehler et al. $2002^{25}$ & I: $93.5 \%$, C: $88.5 \%$ & None & NR & $\begin{array}{l}\text { S. aureus } 51 \% \text {, CNS } 18 \% \text {, } \\
\text { negative } 0 \% \text {, other } 31 \%\end{array}$ \\
\hline Ascherl et al. $1990^{24}$ & $63 \%$ & $\begin{array}{l}\text { >MIC for } 5 \text { days, max. serum } 3.5 \\
\text { mg/L, max. urine NR }\end{array}$ & Max. $10 w k$ & $\begin{array}{l}\text { S. aureus } 51 \% \text {, CNS } 8 \% \text {, } \\
\text { negative } 19 \% \text {, other } 22 \%\end{array}$ \\
\hline Dieckmann et al. $2008^{27}$ & I: $83.3 \%$; C: $85 \%$ & None & NR & $\begin{array}{l}\text { S. aureus, CNS (NS per } \\
\text { group) }\end{array}$ \\
\hline Feil et al. $1990^{28}$ & $91.5 \%$ & $\begin{array}{l}>\text { MIC for } \pm \sim 3 \text { days, max. serum NR, } \\
\text { max. urine NR }\end{array}$ & NR & $\begin{array}{l}\text { S. aureus }(76.5 \%) \text {, CNS, } \\
\text { Pseudomonas (other NS) }\end{array}$ \\
\hline von Hasselbach $1989^{26}$ & $93.1 \%$ & $\begin{array}{l}>\text { MIC for }>5 \text { days, max. serum NR, } \\
\text { max. urine NR }\end{array}$ & NR & $\begin{array}{l}\text { Mainly S. aureus and CNS } \\
\text { (percentages NS) }\end{array}$ \\
\hline Ipsen et al. $1991^{29}$ & $100 \%$ & $\begin{array}{l}>\text { MIC for } \sim 7 \text { days, max. serum } 4 \\
\mathrm{mg} / \mathrm{L}, \text { max. urine } \pm 50 \mathrm{mg} / \mathrm{L}\end{array}$ & NR & $\begin{array}{l}\text { S. aureus } 70 \% \text {, CNS } 10 \% \text {, } \\
\text { E. coli } 10 \% \text {, negative } 10 \%\end{array}$ \\
\hline Letsch et al. $1993^{31}$ & I: $80 \%$, C: $90 \%$ & $\begin{array}{l}\mathrm{I}:>\mathrm{MIC} \text { for }>3 \text { days, max. serum } 1 \mathrm{mg} / \\
\mathrm{L}, \text { max. urine } 20 \mathrm{mg} / \mathrm{L} ; \mathrm{C}:>\mathrm{MIC} \text { for }>3 \\
\text { days, max. serum too low to measure, } \\
\text { max. urine too low to measure }\end{array}$ & NR & $\begin{array}{l}\text { S. aureus } 60 \% \text {, CNS } 15 \% \text {, } \\
\text { negative } 25 \% \text { (NS per group) }\end{array}$ \\
\hline Leung et al. $2015^{32}$ & $88 \%$ & None & NR & $\begin{array}{l}\text { S. aureus } 32 \% \text {, CNS } 22 \% \text {, } \\
\text { negative } 16 \% \text {, others } 30 \%\end{array}$ \\
\hline Wernet et al. $1992^{18}$ & $83 \%$ & $\begin{array}{l}>\text { MIC for } \sim 5 \text { days, max. serum } 0.7 \\
\mathrm{mg} / \mathrm{L} \text {, max. urine NR }\end{array}$ & NR & Mentioned (NS) \\
\hline \multicolumn{5}{|c|}{$\begin{array}{l}* \mathrm{I}=\text { intervention group, } \mathrm{C}=\text { control group, } \mathrm{NR}=\text { not reported, } \mathrm{CNS}=\text { coagulase-negative staphylococci, } \mathrm{NS}=\text { not specified, MIC }=\text { minimal inhibitory } \\
\text { concentration, } \mathrm{S} .=\text { Staphylococcus, and } \mathrm{E} .=\text { Escherichia. } † \text { The } \mathrm{MIC} \text { is defined as }>4 \mathrm{mg} / \mathrm{L} \text { (equal to } 4 \mu \mathrm{g} / \mathrm{mL}) . \text { For serum and urine, the maximum } \\
\text { measured concentrations are shown. Figure } 2 \text { shows additional pharmacokinetic results for gentamicin concentrations in exudate. } \neq \text { Overview of the } \\
\text { most important pathogens and locations; most studies reported these results in greater detail. }\end{array}$} \\
\hline
\end{tabular}


The Journal of Bone \& Joint Surgery - jbjs.org Volume 100-A · Number 24 - December 19, 2018
Antibiotic-Loaded Collagen Sponges in Clinical Treatment of Chronic OSTEOMYelitis

TABLE III (continued)

\begin{tabular}{lllll}
\multicolumn{1}{c}{ Mean Age $(\mathrm{yr})$} & $\begin{array}{c}\text { Mean Follow-up } \\
(\mathrm{mo})\end{array}$ & No. of Sponges & Systemic Antibiotics Applied & $\begin{array}{c}\text { Allograft Combined } \\
\text { with Sponge }\end{array}$ \\
\hline $39.92 / 42.23$ & 1.5 & NR & No & In all cases \\
NR & 48 & $1-2$ (NS per patient) & Yes (NS) & If needed \\
8.8 (range, $0.8-15)$ & 85.2 & NR & Yes (varied between cases) & If needed \\
$70 \%>50 \mathrm{yr}$ & 12 & $1-4$ (NS per patient) & NR & If needed \\
NR & 13.7 & $1-7$ (NS per patient) & NR & If needed \\
51.8 & 12 & $1-5$ (NS per patient) & Yes (5 days IV, 7 wk oral) & NR \\
NR & 20 & NR & NR & If needed \\
$31.6 / 48.9$ & 16.2 & $1-5 / 1-5$ (NS per patient) & Yes (NS) & If needed \\
40.9 & 38.4 & NR & Yes (2 wk IV, 4 wk oral) & NR \\
NR & NR & NR & NR & If needed \\
\hline
\end{tabular}

1 study, and none of the studies assessed effects on bone regeneration. None of the studies reported disease characteristics such as severity or the Cierny-Mader classification.

The follow-up duration in the included studies varied between 6 weeks and 7.1 years. The study by Buehler et al. had a follow-up of 6 weeks because they studied the risk of early reinfection ${ }^{25}$. The other studies had a mean follow-up of 1 to 7.1 years because the authors were more interested in the medium to long-term rate of infection eradication ${ }^{18,24,26-32}$. Pharmacokinetics were also studied in the first 5 to 7 days after surgery.

TABLE IV (continued)

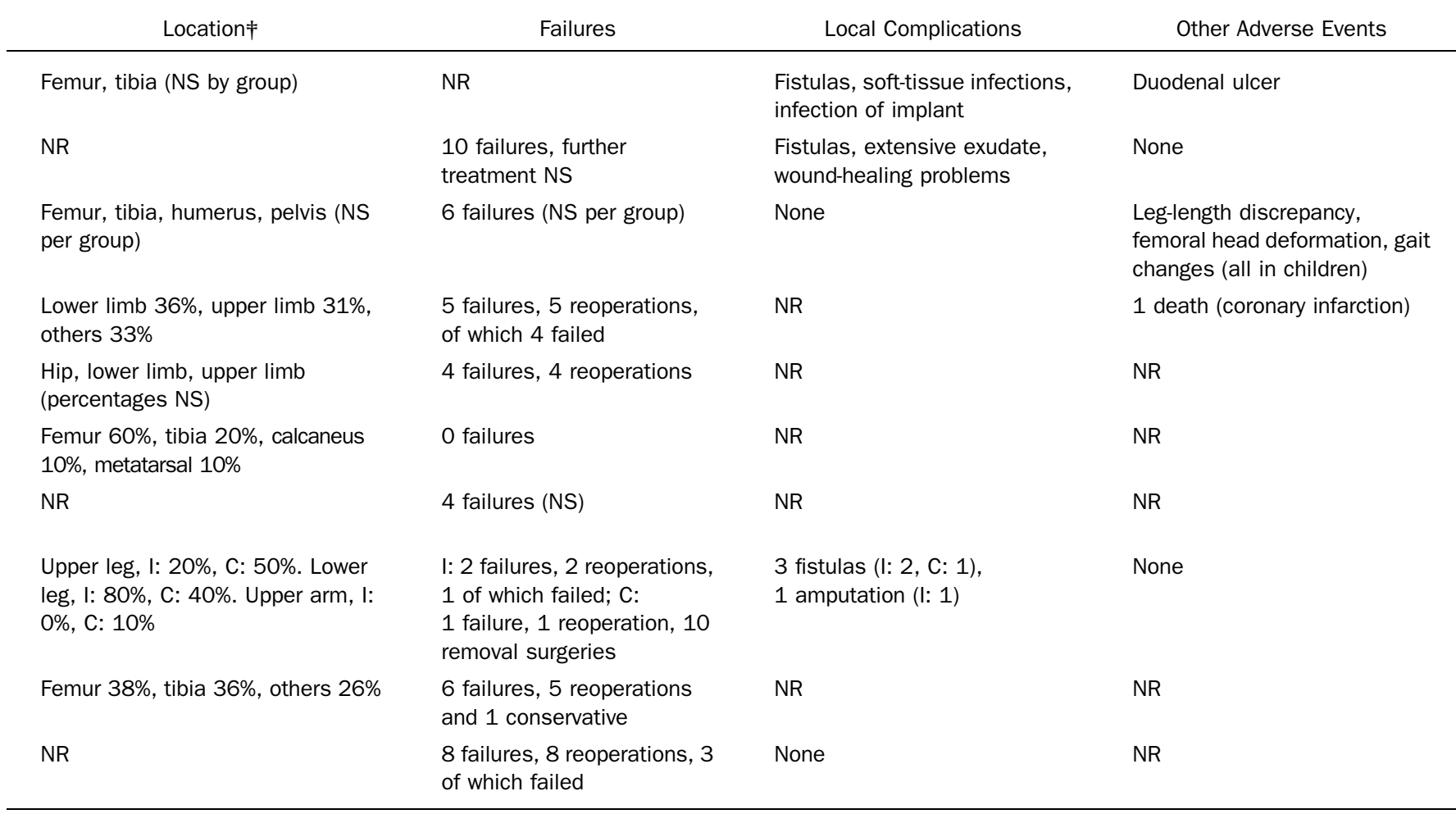


TABLE V Risk of Bias in the Included Studies

\begin{tabular}{|c|c|c|c|c|c|c|c|c|c|c|c|}
\hline Study & Population & Intervention & Allocation & Confounding & Blinding & $\begin{array}{c}\text { Outcome } \\
\text { Assessment }\end{array}$ & Follow-up & $\begin{array}{l}\text { Outcome } \\
\text { Reporting }\end{array}$ & Protocol & $\begin{array}{l}\text { Other } \\
\text { Sources } \\
\text { of Bias }\end{array}$ & Total* \\
\hline Buehler et al. $2002^{25}$ & \pm & \pm & + & + & + & + & - & + & + & \pm & 15 \\
\hline Dieckmann et al. $2008^{27}$ & \pm & \pm & - & \pm & - & + & + & \pm & \pm & \pm & 10 \\
\hline Feil et al. $1990^{28}$ & \pm & + & - & \pm & - & \pm & \pm & - & \pm & \pm & 8 \\
\hline von Hasselbach $1989^{26}$ & \pm & \pm & - & \pm & - & - & \pm & \pm & \pm & - & 6 \\
\hline Kwasny et al. $1994^{30}$ & - & - & - & \pm & - & \pm & + & + & \pm & \pm & 8 \\
\hline Letsch et al. $1993^{31}$ & + & + & + & \pm & - & + & + & \pm & \pm & - & 13 \\
\hline Leung et al. $2015^{32}$ & \pm & \pm & - & \pm & - & + & + & \pm & \pm & \pm & 10 \\
\hline Wernet et al. $1992^{18}$ & \pm & \pm & - & \pm & - & \pm & - & + & \pm & \pm & 8 \\
\hline
\end{tabular}

\section{Quality and Bias}

Even though antibiotic-loaded sponges have been in use for $>25$ years, to our knowledge only 2 comparative studies (i.e., low-quality RCTs) and 1 good-quality cohort study have been performed (Table II). The other studies were low-quality cohort studies or case series, which are all ranked as low-quality evidence. Because of these low levels of evidence, the grade of recommendation for use of these products is also low.

Assessing the overall risk of bias across the studies was not possible because of a lack of heterogeneity resulting from extreme variations in clinical indications, study designs, outcome measurements, and treatment protocols. A critical appraisal reveals several major risks of bias, and a moderate to high overall risk of bias (Table V). The major risks of bias involve study designs, unclear study protocols, and por description of the inclusion and exclusion criteria, which introduce possible selection bias and detection bias. Although outcomes were generally defined clearly, outcome measures were generally not mentioned or not well described. In addition, the majority of studies did not involve any type of control group and the associated statistical analysis. Detailed information about the risks of bias is given in the Appendix.

\section{Results for Gentamicin-Sulfate Sponges}

Gentamicin-sulfate sponges were investigated in 9 studies in which a total of 351 patients were treated. Success rates in the studies varied from $63 \%$ to $100 \%$, with a mean of $91 \%$. The number of implanted sponges per patient was reported in 5 studies but none gave further details or analyzed the relationship between the number of sponges and outcomes (Table III). In addition, the use of pathogen-specific adjuvant antibiotic therapy based on culture results was mentioned in 5 studies, but only 2 studies provided further details. Letsch et al. performed an RCT in which they compared gentamicin-loaded Sulmycin implants (Schering-Plough) with gentamicin-loaded PMMA beads (Septopal; Zimmer Biomet) in a small study population ${ }^{31}$. They reported success rates of $80 \%$ in the Sulmycin group and $90 \%$ in the PMMA group, which were not significantly different. Dieckmann et al. performed a retrospective outcome study regarding osteomyelitis in children in which the success rate was $83 \%$ for gentamicin sponges and $85 \%$ for gentamicin-loaded PMMA beads ${ }^{27}$. The authors used the PMMA beads in cases with large bone defects necessitating bone grafting, because use of the sponges might not permit regeneration of large bone defects. Although they used different treatment strategies based on disease severity or classification, this severity or classification was not reported. The other included studies reported comparable eradication rates for the gentamicin-sulfate implant that were comparable to those in the abovementioned studies; only Ascherl et al. reported a lower success rate, of $63 \%{ }^{24}$. In addition to the low success rates, that study reported numerous complications such as persisting fistulas, prolonged wound exudation, and woundhealing problems, all related to failure of treatment with the collagen sponges. Two other studies reported persisting fistu$\operatorname{las}^{24,31}$ and 1 study reported an amputation, also all related to treatment failure ${ }^{31}$. Good reporting of complications or explanation of treatment failures was lacking in most studies.

The in vivo pharmacokinetics of antibiotic-loaded collagen sponges were reported in 7 studies $^{18,24,26,28-31}$. All data on exudate concentrations were pooled (by estimation, because of the absence of raw data) and are plotted in Figure 2. Figure 2-A shows that the concentration of gentamicin released by the sponges was remarkably comparable across the studies. Ascherl et al. reported relatively low concentrations compared with the other 6 studies, which might be an explanation for their lower eradication rates. Figure 2-B shows that most sponges released the highest concentrations in the first hours after surgery, and the release concentrations dropped by up to $75 \%$ to $90 \%$ within the first 24 to 48 hours after surger $y^{28-30}$. The most striking result to emerge from Figure 2-B is that wound exudate concentrations dropped below therapeutic concentrations after a maximum of 7 days. Letsch et al. compared pharmacokinetics in wound exudate, serum, and urine between the sponge and gentamicin-loaded PMMA bead groups. The exudate concentration for the bead group 
The Journal of Bone \& Joint Surgery - Jbjs. org Volume 100-A · Number $24 \cdot$ December 19, 2018

A Pharmacokinetics in exudate (per study)

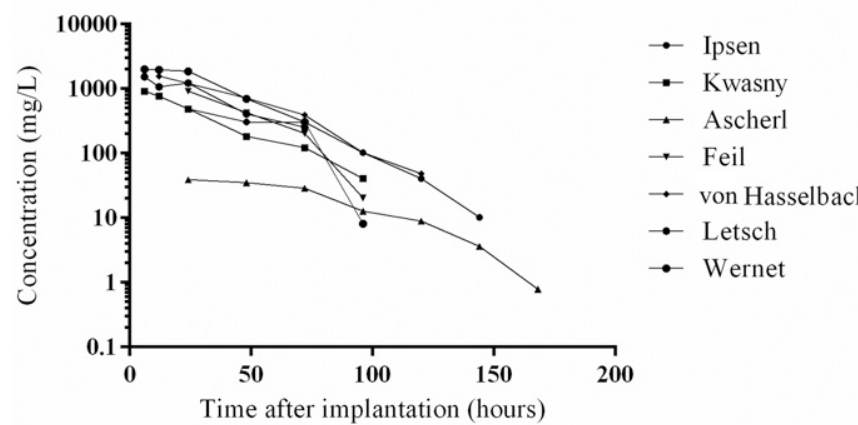

B

Pharmacokinetics in exudate (pooled)

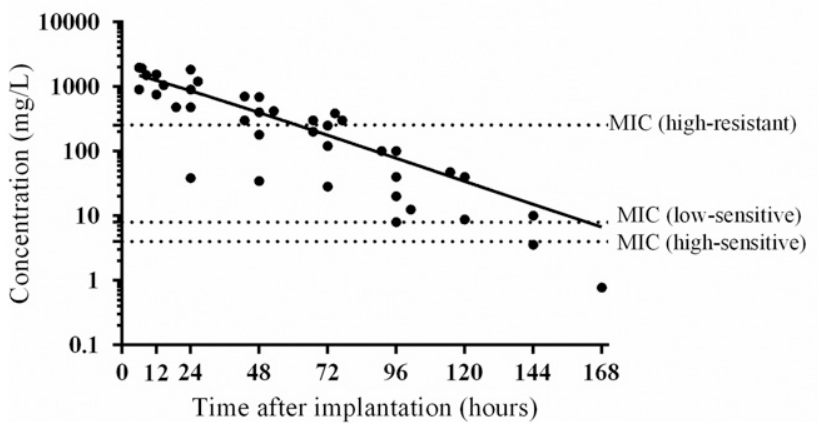

Fig. 2

Gentamicin concentration (on a logarithmic scale) in wound exudate measured over time as reported in the included studies. Values were obtained from the included studies by rough estimation because raw data were not available. Fig. 2-A Decrease in gentamicin-sulfate concentration in each of the included studies. Fig. 2-B Pooled plot of all approximate (estimated) concentrations over the first 7 days after surgery. The nonlinear regression curve (line) suggests that the gentamicin concentration drops below the therapeutic concentration after a maximum of 7 days for highly sensitive pathogens and 3 days for resistant pathogens.

remained stable at $100 \mathrm{mg} / \mathrm{L}$ during the first 3 days, whereas the concentration for the sponge group decreased from 1,500 to $200 \mathrm{mg} / \mathrm{L}^{31}$. Other studies reported concentrations of released gentamicin in wound exudate that ranged from 170 to $6,000 \mathrm{mg} / \mathrm{L}$ after 24 hours and decreased to $20 \mathrm{mg} / \mathrm{L}$ after 3 days and $<5 \mathrm{mg} / \mathrm{L}$ after 5 days (Fig. 2). The mean serum gentamicin concentrations remained $<1 \mathrm{mg} / \mathrm{L}$ in all studies. Only Ipsen et al. and Ascherl et al. mentioned 2 cases with a serum concentration of approximately $4 \mathrm{mg} / \mathrm{L} 6$ to 12 hours after surgery; these concentrations decayed within the following 6 to 12 hours to $<1 \mathrm{mg} / \mathrm{L}^{24,29}$. Extremely high concentrations $(>5,000 \mathrm{mg} / \mathrm{L})$ of gentamicin in exudate during the first hours to days were reported in cases with minimal exudate production, whereas most patients had normal exudate production and consequently a lower antibiotic concentration in the exudate. The relation between the number of implanted sponges and the gentamicin concentrations in serum and exudate was analyzed but did not show any correlation ${ }^{18,24,26,28,29,31}$. In all studies in which the pharmacokinetics of gentamicin-sulfate sponges were evaluated, no signs of toxicity were observed.
Antibiotic-Loaded Collagen Sponges in Clinical Treatment OF Chronic OSTEOMYelitis
Results for Gentamicin-Sulfate/Gentamicin-Crobefate Sponges The study regarding the clinical efficacy of gentamicin-sulfate/ gentamicin-crobefate collagen sponges was a multicenter RCT ${ }^{25}$. The treatment group that received debridement and Septocoll (Zimmer Biomet) combined with autologous bone graft implantation had a $93.5 \%$ success rate, compared with $88.5 \%$ in the control group that received debridement and antibiotic-free autologous bone graft implantation. Neither group received adjuvant systemic antibiotics. In addition to the recurrence of osteomyelitis in the patients with unsuccessful treatment, the authors reported 4 cases of soft-tissue infection, 2 fistulas, and 1 infected sponge in the treatment group and 6 soft-tissue infections in the control group. The follow-up was 6 weeks, and study enrollment was prematurely terminated because of the inability to include enough patients. Only 93 of the 123 included patients finished the study; the high loss to follow-up was not explained. In vivo pharmacokinetics were not reported.

\section{Discussion}

$\mathbf{B}$ ased on this review, the clinical evidence regarding the use B of antibiotic-loaded collagen sponges in the treatment of osteomyelitis is limited: the quality of studies was low to moderate (mainly Level of Evidence IIIb or IV) and the risk of bias was moderate to high.

The eradication rates in the included studies suggest that the sponges show non-inferiority in comparison with PMMA beads. However, taken together with factors such as a short antibiotic release period and reports of wound-healing complications, the added value of these sponges is not indisputable either.

The treatment regimen in all studies involving the gentamicin sulfate-loaded sponges included implantation after radical debridement followed by adjuvant systemic administration of antibiotics, whereas the treatment regimen involving the gentamicin-sulfate/gentamicin-crobefate implant lacked adjuvant antibiotic therapy. Nevertheless, the outcomes for both sponges were comparable, with an overall success rate of $91 \%$. The success rates were also comparable to those reported for treatment with antibiotic-loaded PMMA beads in the literature, which vary from $60 \%$ up to $100 \%^{33-36}$. In addition, beneficial effects of sponges compared with PMMA beads were not proven in the only comparative study performed ${ }^{31}$. There is 1 other study involving comparison of antibiotic-loaded sponges and PMMA beads that yielded promising results, but that study was never published in full ${ }^{37}$.

The in vivo pharmacokinetics of gentamicin-sulfate release were described in several studies; these showed a fast release, seen in high peak concentrations of gentamicin in wound exudate in the first 24 to 48 hours postoperatively (Fig. 2). In the case of gentamicin-sulfate/gentamicin-crobefate sponges, previous pharmacokinetic studies described the concentrations in exudate dropping below the MIC value on postoperative day $2^{38}$ or $5^{39}$. Ruszczak and Friess reviewed the pharmacokinetic pattern of gentamicin release from a comparable implant in vivo in a study of over 1,500 patients with soft-tissue-related and bone-related infections ${ }^{14}$. In accordance with the results of the studies included in the present analysis, gentamicin reached high concentrations 
The Journal of Bone \& Joint Surgery $\cdot$ JBjS. org Volume 100-A · Number 24 · December 19, 2018
Antibiotic-Loaded Collagen Sponges in Clinical Treatment of Chronic Osteomyelitis within 24 hours after surgery. These concentrations vastly exceed the MIC values of high-sensitive, low-sensitive, and highly resistant bacteria ${ }^{14,17,40}$. None of the studies reported gentamicin-related toxicity. Toxic side effects could occur when serum gentamicin concentrations peak above 10 to $12 \mu \mathrm{g} / \mathrm{mL}$ in the first 24 hours or plateau above $2 \mu \mathrm{g} / \mathrm{mL}>48$ hours after surgery ${ }^{14}$. Although no toxicity was reported, it is theoretically possible that some of the fistulas reported in the studies included in the present analysis were actually caused by local cellular toxicity due to the extremely high local antibiotic concentrations within the first hours after implantation, rather than by persisting infection as was assumed in the studies.

Compared with PMMA beads, collagen sponges have some disadvantages regarding pharmacokinetics. Collagen sponges release $95 \%$ of their complete gentamicin load in the first hours ${ }^{41}$. Although Gruessner et al. reported that the concentration released from gentamicin-sulfate/gentamicin-crobefate sponges exceeded MIC values until 10 to 12 days postoperatively ${ }^{39}$, data from the studies included in the present analysis suggest that most sponges only release sufficient amounts of antibiotics for 5 to 7 days (Fig. 2), whereas PMMA beads release concentrations that remain above the MIC for at least 14 days $^{42,43}$. This makes the antibiotic release period of these sponges relatively short for osteomyelitis treatment compared with PMMA beads. However, in comparison to sponges, the secondary removal surgery remains a disadvantage of PMMA beads.

Antibiotic-loaded collagen sponges have proven to be effective in applications other than osteomyelitis treatment: prevention of postoperative wound infection after colorectal surgery ${ }^{44,45}$, prevention of sternal wound infections after cardiac surgery $^{15,46}$, and treatment of a chronic pilonidal sinus ${ }^{47}$. In orthopaedics, they have been studied for infection prophylaxis after amputation surgery ${ }^{48,49}$, spinal surgery ${ }^{50}$, surgery for a shoulder infection $^{51}$, and management of open fractures ${ }^{52}$, all with varying results. This emphasizes that the usefulness of these antibioticloaded collagen sponges in orthopaedic surgery is limited.

To our knowledge, this is the first study reviewing the quality and outcomes of studies on the application of antibiotic-loaded collagen sponges for treatment of chronic osteomyelitis. A strength of this study is its overview of local concentrations of released antibiotics, using pooled data from the included studies. The most important limitation is the poor overall quality of the included studies, which reduces internal validity. This is particularly true with respect to the indications for the use of these sponges, as not all authors mentioned the type of osteomyelitis (acute or chronic) and patients with periprosthetic joint infections were sometimes included. This is of importance because the treatment of these 3 types of orthopaedic infections differs. In addition, the relatively small sample sizes in the studies, unclear designs, and incomplete reporting of the outcome data or of how the outcomes were assessed introduce reporting and detection bias. Thus, pooling of the data in Figure 2 was based on a rough estimation, which might introduce reporting bias. With respect to external validity, incomplete reporting of patient population characteristics may hamper the interpretation and generalizability of the results of the studies.

A systematic review of other biodegradable antibioticloaded bone-graft substitutes revealed antibacterial effects that resembled those of antibiotic-loaded sponges, in terms of clinical efficacy, and the quality of those studies was comparable as well ${ }^{53}$. Recent studies might suggest a lower rate of local complications with these other biomaterials compared with antibiotic-loaded sponges, but success rates remain comparable ${ }^{54,55}$. However, a good comparison of these materials would require large prospective clinical trials.

In conclusion, this systematic review did not reveal compelling evidence for the clinical efficacy of antibiotic-loaded collagen sponges in the treatment of chronic osteomyelitis. In addition, this review highlights the absence of high-quality evidence, which hampers good evidence-based decision-making. Given this current knowledge, these antibiotic-loaded collagen sponges should only be applied with care and consideration in clinical practice. High-quality (comparative) studies are a necessary next step for future research to obtain more definitive evidence.

\section{Appendix}

eA Tables describing the search strategy, the general criteria for assessing the risk of bias, and the risk-of-bias assessments for the individual studies are available with the online version of this article as a data supplement at jbjs.org (http:// links.lww.com/JBJS/E940).

T.A.G. van Vugt, $\mathrm{MD}^{1}$

J.M.B. Walraven, $\mathrm{MD}^{1}$

J.A.P. Geurts, $\mathrm{MD}, \mathrm{PhD}^{1}$

J.J.C. Arts, $\mathrm{MSc}, \mathrm{PhD}^{1}$

${ }^{1}$ Department of Orthopaedic Surgery (T.A.G.v.V., J.A.P.G., and J.J.C.A.) and Faculty of Health Medicine and Life Sciences (J.M.B.W.), Maastricht University Medical Centre (MUMC+), Maastricht, the Netherlands

E-mail address for T.A.G. van Vugt: tom.van.vugt@mumc.nl

E-mail address for J.M.B. Walraven:

jmb.walraven@maastrichtuniversity.com

E-mail address for J.A.P. Geurts: j.geurts@mumc.nl

E-mail address for J.J.C. Arts: j.arts@mumc.nl

ORCID iD for T.A.G. van Vugt: 0000-0002-5430-5411

\section{References}

1. Lew DP, Waldvogel FA. Osteomyelitis. Lancet. 2004 Jul 24-30;364(9431):369-79. 2. Parvizi J, Ghanem E, Azzam K, Davis E, Jaberi F, Hozack W. Periprosthetic infection: are current treatment strategies adequate? Acta Orthop Belg. 2008 Dec;74(6):793-800.
3. Phillips JE, Crane TP, Noy M, Elliott TS, Grimer RJ. The incidence of deep prosthetic infections in a specialist orthopaedic hospital: a 15-year prospective survey. J Bone Joint Surg Br. 2006 Jul;88(7):943-8. 
The Journal of Bone \& Joint Surgery $\cdot$ Jbjs.org Volume 100-A - Number $24 \cdot$ December 19, 2018
Antibiotic-Loaded Collagen Sponges in Clinical Treatment of Chronic OSTEOMYelitis
4. Trampuz A, Zimmerli W. Diagnosis and treatment of infections associated with fracture-fixation devices. Injury. 2006 May;37(Suppl 2):S59-66.

5. Walter G, Kemmerer M, Kappler C, Hoffmann R. Treatment algorithms for chronic osteomyelitis. Dtsch Arztebl Int. 2012 Apr;109(14):257-64. Epub 2012 Apr 6.

6. Zimmerli W, Sendi P. Orthopaedic biofilm infections. APMIS. 2017 Apr;125(4): 353-64.

7. Kluin OS, van der Mei HC, Busscher HJ, Neut D. Biodegradable vs nonbiodegradable antibiotic delivery devices in the treatment of osteomyelitis. Expert Opin Drug Deliv. 2013 Mar;10(3):341-51. Epub 2013 Jan 6.

8. Neut D, van de Belt H, Stokroos I, van Horn JR, van der Mei HC, Busscher HJ. Biomaterial-associated infection of gentamicin-loaded PMMA beads in orthopaedic revision surgery. J Antimicrob Chemother. 2001 Jun;47(6):885-91.

9. Neut $D$, van de Belt $H$, van Horn JR, van der Mei HC, Busscher HJ. Residual gentamicin-release from antibiotic-loaded polymethylmethacrylate beads after 5 years of implantation. Biomaterials. 2003 May;24(10):1829-31.

10. Geurts J, Chris Arts JJ, Walenkamp GH. Bone graft substitutes in active or suspected infection. Contra-indicated or not? Injury. 2011 Sep;42(Suppl 2):S82-6. Epub 2011 Jul 16.

11. Jacobs MR. Optimisation of antimicrobial therapy using pharmacokinetic and pharmacodynamic parameters. Clin Microbiol Infect. 2001 Nov;7(11):589-96.

12. El-Husseiny M, Patel S, MacFarlane RJ, Haddad FS. Biodegradable antibiotic delivery systems. J Bone Joint Surg Br. 2011 Feb;93(2):151-7.

13. Chang WK, Srinivasa S, MacCormick AD, Hill AG. Gentamicin-collagen implants to reduce surgical site infection: systematic review and meta-analysis of randomized trials. Ann Surg. 2013 Jul;258(1):59-65.

14. Ruszczak Z, Friess W. Collagen as a carrier for on-site delivery of antibacterial drugs. Adv Drug Deliv Rev. 2003 Nov 28;55(12):1679-98.

15. Friberg $O$, Svedjeholm R, Söderquist B, Granfeldt H, Vikerfors T, Källman J. Local gentamicin reduces sternal wound infections after cardiac surgery: a randomized controlled trial. Ann Thorac Surg. 2005 Jan;79(1):153-61; discussion 161-2.

16. Mehta S, Humphrey JS, Schenkman DI, Seaber AV, Vail TP. Gentamicin distribution from a collagen carrier. J Orthop Res. 1996 Sep;14(5):749-54.

17. Stemberger A, Grimm H, Bader F, Rahn HD, Ascherl R. Local treatment of bone and soft tissue infections with the collagen-gentamicin sponge. Eur J Surg Suppl. 1997;578:17-26.

18. Wernet E, Ekkernkamp A, Jellestad H, Muhr G. [Antibiotic-containing collagen sponge in therapy of osteitis]. Unfallchirurg. 1992 May;95(5):259-64.

19. Moher D, Liberati A, Tetzlaff J, Altman DG, PRISMA Group. Preferred reporting items for systematic reviews and meta-analyses: the PRISMA statement. J Clin Epidemiol. 2009 Oct;62(10):1006-12. Epub 2009 Jul 23.

20. Liberati A, Altman DG, Tetzlaff J, Mulrow C, Gøtzsche PC, loannidis JP, Clarke M, Devereaux PJ, Kleijnen J, Moher D. The PRISMA statement for reporting systematic reviews and meta-analyses of studies that evaluate health care interventions: explanation and elaboration. J Clin Epidemiol. 2009 Oct;62(10):e1-34. Epub 2009 Jul 23.

21. Centre for Evidence-Based Medicine. Oxford Centre for Evidence-Based Medicine - levels of evidence 2009. http://www.cebm.net/index.aspx?o=1025. Accessed 2018 Jan 18.

22. Heneghan C. EBM resources on the new CEBM website. Evid Based Med. 2009 Jun;14(3):67.

23. Higgins JPT, Green S. Cochrane handbook for systematic reviews of interventions. 2011. http://training.cochrane.org/handbook. Accessed 2018 Jan 18. 24. Ascherl R, Stemberg A, Lechner F, Blümel G. [Local treatment of infection with collagen gentamicin]. Aktuelle Probl Chir Orthop. 1990;34:85-93. German.

25. Buehler M, Vécsei V, Gruessner U. Controlled, single-blind, international, multicentre study on the efficacy and tolerability of Gentamicin-Collagen-Fleece Septocoll $\circledast$ in subjects with autologous cancellous bone grafts following chronic osteomyelitis and/or infected non-union. 2002.

26. von Hasselbach $\mathrm{C}$. [Clinical aspects and pharmacokinetics of collagengentamicin as adjuvant local therapy of osseous infections]. Unfallchirurg. 1989 Sep;92(9):459-70. German.

27. Dieckmann R, Hardes J, Ahrens H, Flieger S, Gosheger G, Götze C, Rödl R. [Treatment of acute and chronic osteomyelitis in children]. Z Orthop Unfall. 2008 May-Jun;146(3):375-80. German.

28. Feil J, Bohnet S, Neugebauer R, Rübenacker S. [Bioresorbable collagengentamicin compound as local antibiotic therapy]. Aktuelle Probl Chir Orthop. 1990; 34:94-103. German.

29. Ipsen T, Jørgensen PS, Damholt V, Tørholm C. Gentamicin-collagen sponge for local applications. 10 cases of chronic osteomyelitis followed for 1 year. Acta Orthop Scand. 1991 Dec;62(6):592-4.

30. Kwasny $\mathrm{O}$, Bockhorn $\mathrm{G}$, Vécsei $\mathrm{V}$. The use of gentamicin collagen floss in the treatment of infections in trauma surgery. Orthopedics. 1994 May;17(5):421-5.

31. Letsch R, Rosenthal E, Joka T. [Local antibiotic administration in osteomyelitis treatment-a comparative study with two different carrier substances]. Aktuelle Traumatol. 1993 Nov;23(7):324-9. German.
32. Leung AH, Hawthorn BR, Simpson AH. The effectiveness of local antibiotics in treating chronic osteomyelitis in a cohort of 50 patients with an average of 4 years follow-up. Open Orthop J. 2015 Jul 31;9:372-8.

33. Blaha JD, Calhoun JH, Nelson CL, Henry SL, Seligson D, Esterhai JL Jr, Heppenstall RB, Mader J, Evans RP, Wilkins J, Patzakis MJ, Spiegel P. Comparison of the clinical efficacy and tolerance of gentamicin PMMA beads on surgical wire versus combined and systemic therapy for osteomyelitis. Clin Orthop Relat Res. 1993 Oct;295:8-12.

34. Evans RP, Nelson CL. Gentamicin-impregnated polymethylmethacrylate beads compared with systemic antibiotic therapy in the treatment of chronic osteomyelitis. Clin Orthop Relat Res. 1993 Oct;295:37-42.

35. Jerosch J, Lindner N, Fuchs S. [Results of long-term therapy of chronic, posttraumatic osteomyelitis with gentamycin PMMA chains]. Unfallchirurg. 1995 Jun; 98(6):338-43. German

36. Walenkamp GH, Kleijn LL, de Leeuw M. Osteomyelitis treated with gentamicinPMMA beads: 100 patients followed for 1-12 years. Acta Orthop Scand. 1998 Oct; 69(5):518-22.

37. Bettin $\mathrm{D}$, Winkler $\mathrm{H}$. Comparative evaluation of results after local antibiotic therapy with gemtamycin in form of beads and fleece. Bone Joint J. 2009;91-B(Suppl. II):311. 38. Moser A. Comparative human pharmacokinetics of 2 gentamicin-containing collagen carriers. In: Walenkamp GHIM, editor. Biomaterials in surgery. Stuttgart: Thieme; 1998. p 21-5.

39. Gruessner U KH, Langendorff H-U, Geyer D. Human pharmacokinetics of the new gentamicin collagen fleece Septocoll ${ }^{\circledR}$ in bone surgery. Osteosynthese Int. 2000;8:S43-S8.

40. Young LS, Hewitt WL. Activity of five aminoglycoside antibiotics in vitro against gram-negative bacilli and Staphylococcus aureus. Antimicrob Agents Chemother. 1973 Dec;4(6):617-25.

41. Sørensen TS, Sørensen Al, Merser S. Rapid release of gentamicin from collagen sponge. In vitro comparison with plastic beads. Acta Orthop Scand. 1990 Aug;61(4): 353-6.

42. Becker PL, Smith RA, Williams RS, Dutkowsky JP. Comparison of antibiotic release from polymethylmethacrylate beads and sponge collagen. J Orthop Res. 1994 Sep;12(5):737-41.

43. Walenkamp GH, Vree TB, van Rens TJ. Gentamicin-PMMA beads. Pharmacokinetic and nephrotoxicological study. Clin Orthop Relat Res. 1986 Apr;205:171-83. 44. de Bruin AF, Gosselink MP, Wijfels NA, Coene PP, van der Harst E. Local gentamicin reduces perineal wound infection after radiotherapy and abdominoperineal resection. Tech Coloproctol. 2008 Dec;12(4):303-7. Epub 2008 Nov 18.

45. Rutten HJ, Nijhuis PH. Prevention of wound infection in elective colorectal surgery by local application of a gentamicin-containing collagen sponge. Eur J Surg Suppl. 1997;578:31-5.

46. Schimmer C, Özkur M, Sinha B, Hain J, Gorski A, Hager B, Leyh R. Gentamicincollagen sponge reduces sternal wound complications after heart surgery: a controlled, prospectively randomized, double-blind study. J Thorac Cardiovasc Surg. 2012 Jan;143(1):194-200. Epub 2011 Aug 31.

47. Yetim I, Ozkan OV, Dervişoglu A, Erzurumlu K, Canbolant E. Effect of gentamicinabsorbed collagen in wound healing in pilonidal sinus surgery: a prospective randomized study. J Int Med Res. 2010 May-Jun;38(3):1029-33.

48. Spruit M, Bosman $\mathrm{CH}$. Revision of failed below knee amputations. Local debridement with gentamicin collagen. Eur J Surg. 1994 May;160(5):267-70. 49. Varga M, Sixta B, Bem R, Matia I, Jirkovska A, Adamec M. Application of gentamicin-collagen sponge shortened wound healing time after minor amputations in diabetic patients - a prospective, randomised trial. Arch Med Sci. 2014 May 12; 10(2):283-7. Epub 2014 May 13.

50. Rohde V, Meyer B, Schaller C, Hassler WE. Spondylodiscitis after lumbar discectomy. Incidence and a proposal for prophylaxis. Spine (Phila Pa 1976). 1998 Mar 1;23(5):615-20.

51. Attmanspacher W, Dittrich V, Schätzler A, Stedtfeld HW. [Mid-term outcome of postoperative infections of the shoulder]. Unfallchirurg. 2000 Dec;103(12): 1048-56. German.

52. Chaudhary S, Sen RK, Saini UC, Soni A, Gahlot N, Singh D. Use of gentamicinloaded collagen sponge in internal fixation of open fractures. Chin J Traumatol. 2011;14(4):209-14.

53. van Vugt TA, Geurts J, Arts JJ. Clinical application of antimicrobial bone graft substitute in osteomyelitis treatment: a systematic review of different bone graft substitutes available in clinical treatment of osteomyelitis. Biomed Res Int. 2016; 2016:6984656. Epub 2016 Jan 21.

54. Lindfors N, Geurts J, Drago L, Arts JJ, Juutilainen V, Hyvönen P, Suda AJ, Domenico A, Artiaco S, Alizadeh C, Brychcy A, Bialecki J, Romanò CL. Antibacterial bioactive glass, S53P4, for chronic bone infections - a multinational study. Adv Exp Med Biol. 2017;971:81-92.

55. McNally MA, Ferguson JY, Lau AC, Diefenbeck M, Scarborough M, Ramsden AJ, Atkins BL. Single-stage treatment of chronic osteomyelitis with a new absorbable, gentamicin-loaded, calcium sulphate/hydroxyapatite biocomposite: a prospective series of 100 cases. Bone Joint J. 2016 Sep;98-B(9):1289-96. 